\title{
Progress Toward Integrated Management of Lettuce Drop
}

Cultivated lettuce (Lactuca sativa) is thought to have originated around the Mediterranean from wild lettuce, $L$. serriola, commonly referred to as the prickly lettuce. The resemblance of wild lettuce to its probable wild progenitor (L. serriola) supports this hypothesis. The earliest written records of Herodotus indicate lettuce cultivation dating back to 550 B.C., although its appearance in stylized paintings in 4,500-year-old Egyptian tombs indicates a much more ancient history. Lettuce was brought into the New World by Christopher Columbus (54). Early in the settlement of North America by Europeans, lettuce was important and grown in market gardens near cities primarily for local consumption, as well as in home gardens. The development of the western shipping industry during the early part of this century transformed lettuce into an economically viable commodity (54).

Types of lettuce. Since its domestication as a vegetable crop, a medley of lettuce types has been described. The cultivation of specific types of lettuce is dictated by a combination of geography, climate, consumer preference, and market forces. The common types of lettuce grown throughout the world are crisphead, romaine, green or red leaf, butterhead, Batavia, Latin, stem, and oilseed types. Crisphead lettuce is also commonly referred to as "iceberg," the name of an old cultivar and technically an incorrect designation for crisphead lettuce. The four principal types of lettuce that predominate commercial production in the United States are crisphead (the most widely grown), romaine, green or red leaf, and butterhead (Fig. 1). The characteristics that distinguish these four types are the formation of a head, its shape and size, and tex-

Dr. Subbarao's address is: Department of Plant Pathology, University of California, Davis, c/o U.S. Agricultural Research Station, 1636 E. Alisal St., Salinas, CA 93905;

E-mail: kvsubbarao@ucdavis.edu

Publication no. D-1998-0717-03F

(C) 1998 The American Phytopathological Society ture (54). Lettuce is rich in vitamins A and $\mathrm{C}$, and minerals such as calcium, potassium, and sodium. Crisphead lettuce has by far the least amount of vitamins and minerals, followed by increasingly higher amounts in butterhead, leaf, and romaine types (54). The generalized growth stages of a crisphead lettuce are depicted in Figure 2.

Lettuce production. Major lettuce producing countries of the world include Belgium, France, Germany, Great Britain, Italy, the Netherlands, Spain, and the United States. Lettuce production also occurs to a lesser extent in Australia, Japan, Israel, and Taiwan (55). The United States is the largest producer of lettuce, with an aggregate production area of 108,000 ha and a farmgate value of more than $\$ 1$ billion annually (Table 1). Crisphead lettuce accounts for $75 \%$ of the production area and $80 \%$ of the crop value. The remaining production in the United States is comprised of leaf, butterhead, and romaine types.

In the United States, commercial production of all lettuce types is concentrated in California and Arizona. California produces more lettuce than any other country in the world, and Arizona produces more than most other countries. Annually, lettuce production in these two states alone accounts for nearly $90 \%$ of the total U.S. production, with California contributing approximately $75 \%$ of the total (Table 1). The remaining $10 \%$ of U.S. lettuce is grown in Colorado, Florida, Michigan, New Mexico, New York, New Jersey, and Ohio (54).

In California, major lettuce production is concentrated in the coastal areas of the Salinas and Santa Maria valleys. Although lettuce production can occur year-round in both valleys, in Salinas it is interrupted by the "lettuce-free" period between 7 and 21 December mandated by Monterey County as a means of avoiding lettuce mosaic in succeeding lettuce crops. Significant production occurs during late fall and winter in the San Joaquin, Imperial, and Palo Verde valleys in California. Most of the Arizona production occurs during the late fall and winter (54) and is concentrated in the western part of the state.

Three diseases that result in significant economic losses worldwide and in California are downy mildew (Bremia lactucae), corky root (Rhizomonas suberifaciens), and lettuce drop. In this paper, only lettuce drop, caused by Sclerotinia sclerotiorum and $S$. minor, will be discussed.

Table 1. Major lettuce producing countries of the world ${ }^{x}$

\begin{tabular}{|c|c|c|c|}
\hline $\begin{array}{l}\text { Country } \\
\text { State }\end{array}$ & $\begin{array}{l}\text { Production area } \\
\text { (ha) }\end{array}$ & $\begin{array}{c}\text { Production } \\
(t)\end{array}$ & $\begin{array}{l}\text { Value (\$) } \\
(\times \mathbf{1 0 0 0})\end{array}$ \\
\hline Australia & 4,000 & 99,000 & 43,000 \\
\hline Belgium & 2,400 & 87,600 & $\ldots{ }^{\mathrm{y}}$ \\
\hline France & 13,400 & 344,500 & $\ldots$ \\
\hline Germany & 4,900 & 118,800 & $\ldots$ \\
\hline Israel & 1,450 & 90,000 & 34,800 \\
\hline Italy & 58,000 & & \\
\hline Japan & 23,000 & 520,000 & $1,500,000$ \\
\hline The Netherlands & 1,000 & & 63,000 \\
\hline Spain & 34,000 & 968,000 & \\
\hline United Kingdom & 6,900 & 201,000 & 73,000 \\
\hline United States ${ }^{\mathrm{z}}$ & 105,000 & $3,800,000$ & $1,100,000$ \\
\hline Arizona & 24,000 & 900,000 & 180,000 \\
\hline California & 72,500 & $2,800,000$ & 872,000 \\
\hline
\end{tabular}




\section{Lettuce Drop}

The disease was termed Sclerotiniose when it was first discovered, but drop is the most common name used today. In the United States, Stevens and Hall (57) reported the appearance of the disease in 1890 on greenhouse-grown lettuce in Massachusetts. The occurrence of drop in Florida was reported in 1896 and from North Carolina in 1897. The appearance of drop was later documented from Pennsylvania, Kentucky, and Arizona (53). Although the symptoms described in some of these earlier reports matched the symptoms caused by Sclerotinia, they were attributed to pathogens such as Botrytis sp., Sclerotium rolfsii, and Rhizoctonia sp. The definitive corroboration of Sclerotinia spp. as the cause of lettuce drop was provided by Smith (56) in 1900.

Lettuce drop has been reported from all lettuce-growing regions of the world $(11,22,27,34,42,50)$. In the United States, lettuce drop occurs in all major lettuceproducing states, including Arizona, California, Florida, New Jersey, and New York. It is common to find some symptomatic plants in most production areas. Precise statistics for annual losses caused by let- tuce drop are not available, but they have varied from $<1 \%$ to nearly $75 \%$ (53). Conditions such as cropping history, irrigation and tillage methods, and other environmental and cultural characteristics of the field influence losses. In California, average seasonal losses of up to $15 \%$ from lettuce drop are common, and individual fields with losses of up to $60 \%$ are not uncommon. Economic losses are increased by higher lettuce prices in some seasons.

All types of lettuce are affected by Sclerotinia spp. Because most land is in crisphead lettuce production, most of the information was developed from lettuce drop on crisphead lettuce, but this information is applicable to all types of lettuce.

Causal agents. Lettuce drop is caused by Sclerotinia sclerotiorum and $S$. minor. As early as 1900, Smith (56) noticed the distinction between cultures of Sclerotinia that produced large and small sclerotia. Subsequently, Jagger (34) observed that lettuce drop in New York was caused mostly by the undescribed species of Sclerotinia that produced only small sclerotia, and later described the species as $S$. minor. Both species are widely distributed wherever lettuce is grown, but only one species or the other causes losses in most locations. Reports from Canada (44), New Zealand (27), and New York (1) indicate the disease is caused by only $S$. minor, and in most other regions except California, lettuce drop is predominantly caused by $S$. sclerotiorum. California is unique with respect to the distribution of the two species in lettuce production areas. In the Salinas Valley and adjoining coastal valleys, the predominant cause of lettuce drop is $S$. minor, while in the San Joaquin Valley, the majority of lettuce drop infections are caused by $S$. sclerotiorum. In the Santa Maria and Lompoc areas, infections are caused by either species, although the dominant species is $S$. minor. Rare infections by $S$. sclerotiorum are observed in the Salinas Valley. They originate from germinated sclerotia, whereas in the San Joaquin Valley, the majority of infections caused by this species originate from airborne ascospores. The reasons for these specific niches, and the resultant geographical isolation, are unknown.

Even though Smith (56) noticed the distinction between Sclerotinia producing the large and small sclerotia as early as 1900 , Jagger (34) determined that the pathogen
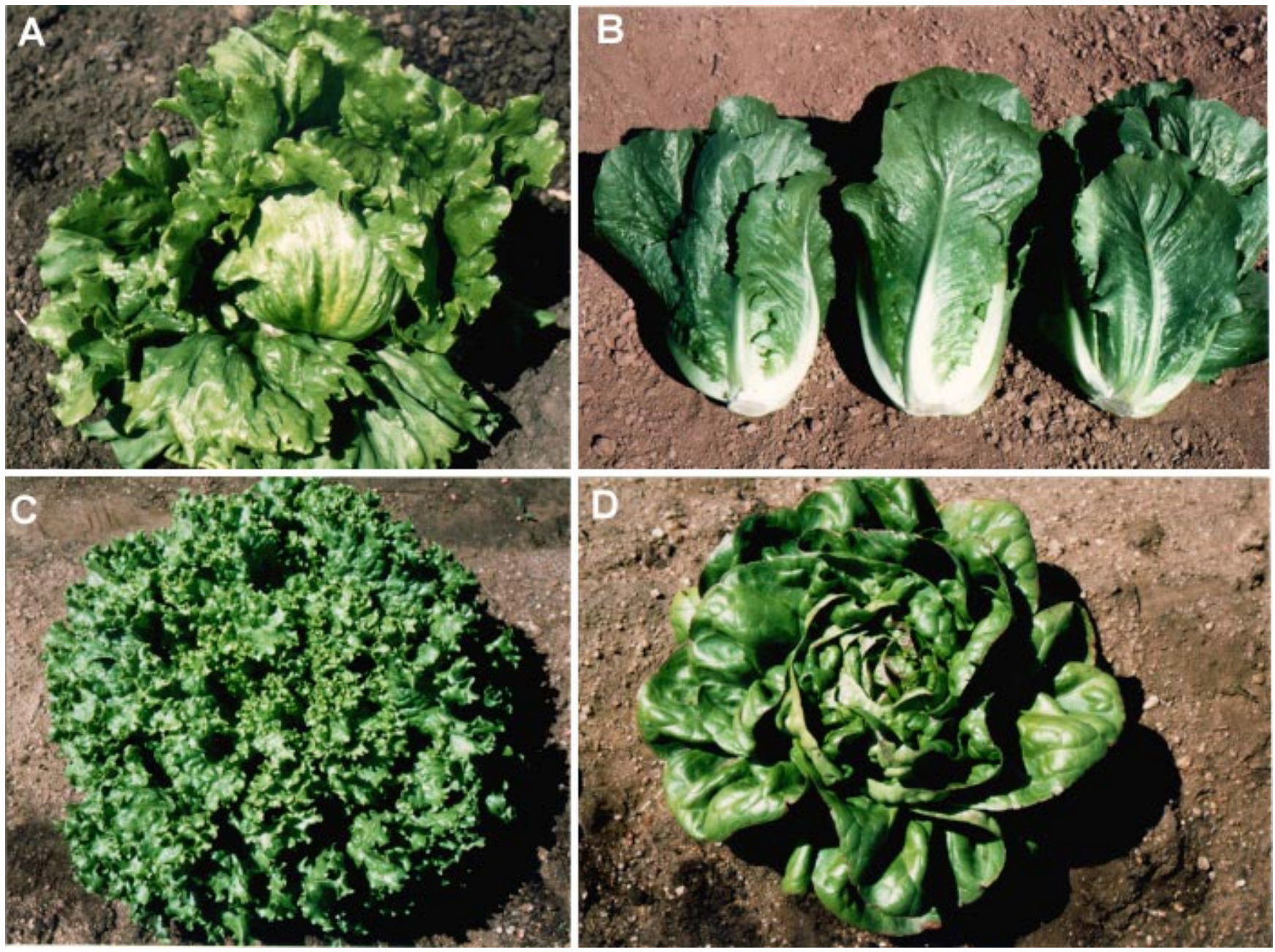

Fig. 1. Lettuce types cultivated in the United States: (A) crisphead, (B) romaine, (C) green leaf, and (D) butterhead. Reprinted with permission from the American Phytopathological Society, St. Paul, MN. 
producing smaller sclerotia was a new species. Nomenclatural problems persisted in Sclerotinia spp. until the late 1970s. For some time, the two pathogens were referred to as S. sclerotiorum (=Whetzelinia sclerotiorum [17]) and S. sclerotiorum minor in the literature (41). Because of the difficulty in delineating species based on characteristics such as the sizes of sclerotia, asci, and ascospores, Purdy (53) grouped these two species along with two other species. Others found enough distinctive characteristics in the size, shape, amount, and pattern of sclerotia formation in culture media, types of tissue lining apothecia, and number of nuclei in the ascospores to call them distinct species (35). Based on this work, the two causal agents of lettuce drop have been routinely designated $S$. minor and $S$. sclerotiorum.

The distinctive features of $S$. minor include mostly circular $(0.5$ to $2.0 \mathrm{~mm}$ diameter) sclerotia (Fig. 3A) and tetranucleate ascospores. In addition, carpogenic germination and production of apothecia are extremely rare because sclerotia germinate eruptively. In contrast, sclerotia of $S$. sclerotiorum measure 2 to $20 \times 3$ to $7 \mathrm{~mm}$ and are irregularly shaped (Fig. 3A). Each sclerotium germinates carpogenically, producing one to several apothecia that are usually cup-shaped but sometimes are ex- panded and flat with a central dimple (35). Apothecia are usually white, yellow, or a shade of brown (Fig. 3B). Asci are cylindric-clavate, measuring up to $130 \times 10$ $\mathrm{mm}$, and contain eight binucleate ascospores. The ascospores are nonseptate, uniseriate, hyaline, and elliptical ( 9 to $13 \times$ 4 to $5 \mathrm{~mm}$ ). Application of restriction fragment length polymorphisms in nuclear and mitochondrial DNA has essentially confirmed that the two species of Sclerotinia are distinct (35).

Host range. Host specificity is not present in either species of Sclerotinia. S. sclerotiorum has an unusually broad host range, infecting a wide range of host plants, including many economically important crop species. S. minor infects fewer hosts than $S$. sclerotiorum but has a wider host range than most plant pathogens $(15,45)$.

The most recent host index (15) indicates that $S$. sclerotiorum is pathogenic to 408 plant species in 278 genera representing 78 families. A majority of these are herbaceous, dicotyledonous plant species, but several monocotyledonous and gymnosperm species are also infected by $S$. sclerotiorum. In addition, it infects one Pteridophyte species (15). In contrast, S. minor occurs on 94 plant species in 66 genera representing 21 families. $S$. minor is known to infect only Angiosperms. It infects only two monocots (45). Within the Asteraceae, to which lettuce belongs, $S$. minor infects 21 species and $S$. sclerotiorum 106 species $(15,45)$.

Symptoms. The common name of the disease on lettuce typifies the final symptoms observed on infected plants. Within a mostly healthy field, one may find infected plants that have collapsed entirely in less than 2 days-hence the name drop. Lettuce drop occurs in two phases. The first phase occurs at the rosette stage (Figs. 2 and 4A, $\mathrm{B}$, and $\mathrm{C}$ ) or immediately after thinning ( 3 to 4 weeks after seedling emergence) on a very low percentage of plants. The second economically significant phase occurs at or near crop maturity (Figs. 2 and 5A and B). The initial symptom is a stressed appearance due to wilting of the outermost leaves.

Infections from soilborne sclerotia and airborne ascospores are different. As infection from soilborne sclerotia progresses toward other leaf layers, the entire plant, including the head, wilts. Layers of collapsed leaves lay flat on the soil surface, giving the plant a yellowish color. Similar symptoms could result from heavy infestation by lettuce-root aphids, but the usual soft watery decay that follows on both above- and belowground plant parts is unique to lettuce drop. Subsequently, under
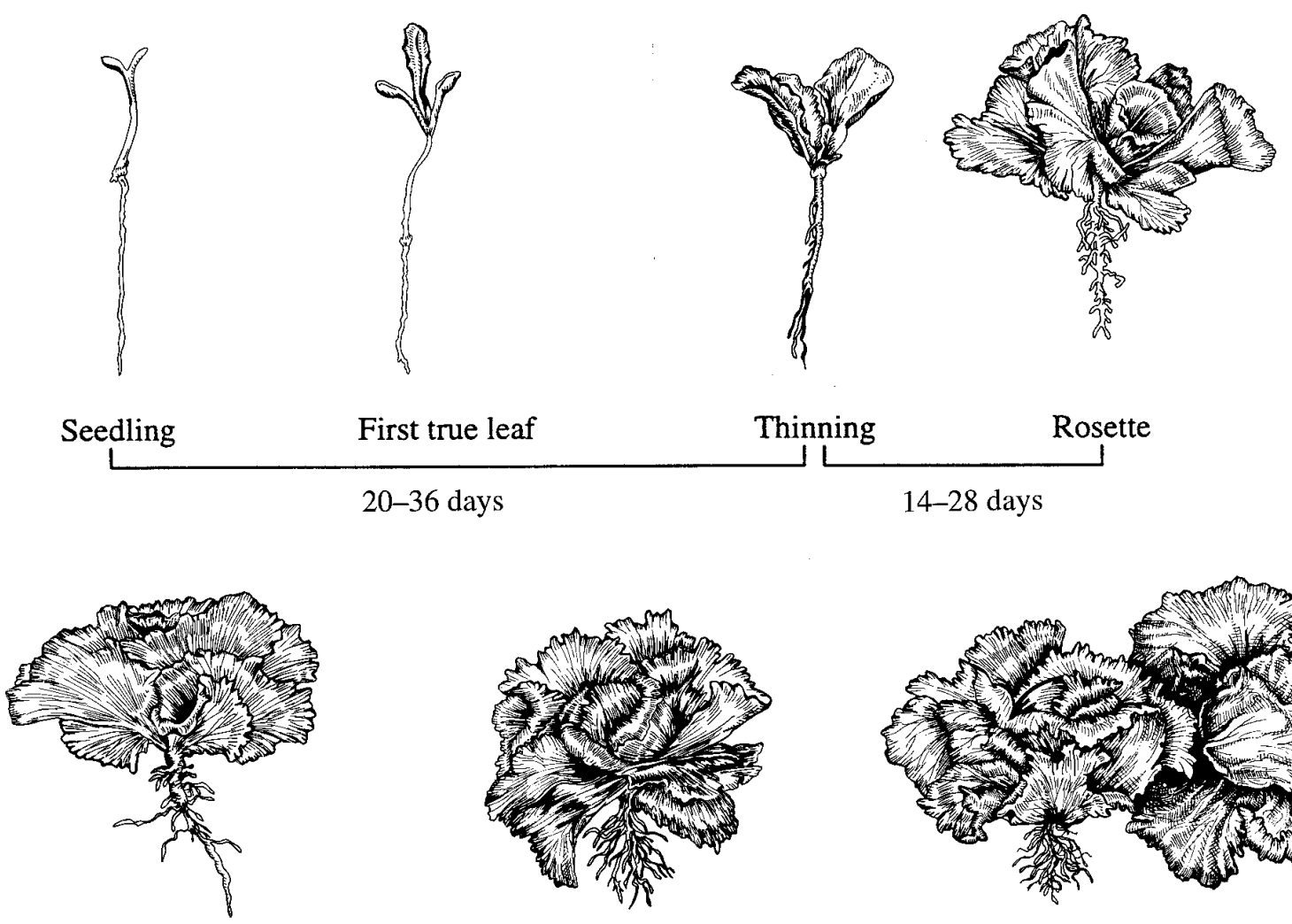

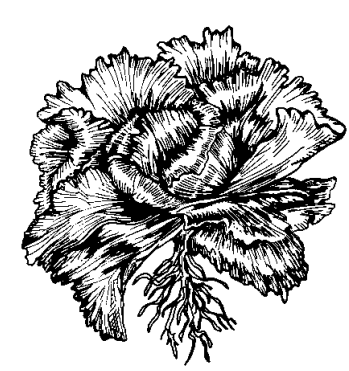

Mid-heading

Early-heading 10-26 days

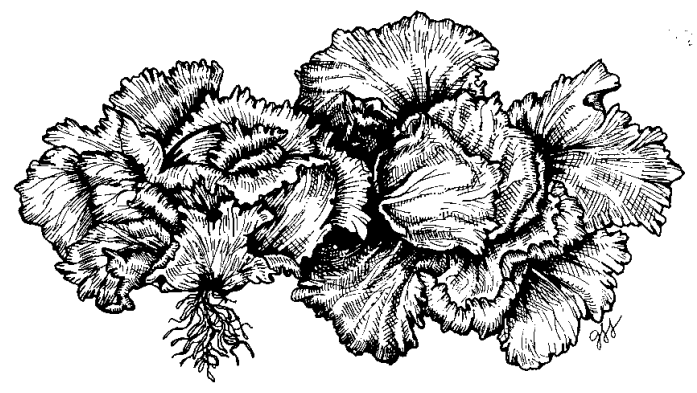

Mature head 16-30 days

Fig. 2. Typical growth stages of crisphead lettuce. Reprinted with permission from the American Phytopathological Society, St. Paul, MN. 
moist conditions, the fungus produces a snowy white mycelium on infected plant parts (Fig. 6A). Black sclerotia are produced on the lower surface of the leaves touching the soil, around the crown, and throughout the taproot (59). Their size depends on fungal species and the temperature during their formation $(13,33)$.

When airborne ascospores initiate infection, losses can be as high as $70 \%$. Symptoms are similar to those described above, except they originate on exposed areas of the lettuce plant, where the ascospores settle and infect. Abundant white, cottony mycelium develops on affected tissues, subsequently producing large, irregularly shaped black sclerotia (Fig. 6B).

Pathogenesis. The pathogenesis of diseases caused by Sclerotinia spp. is complex, and much of the current knowledge on pathogenesis comes from studies on $S$. sclerotiorum (39). The ability of Sclerotinia spp. to infect and penetrate host
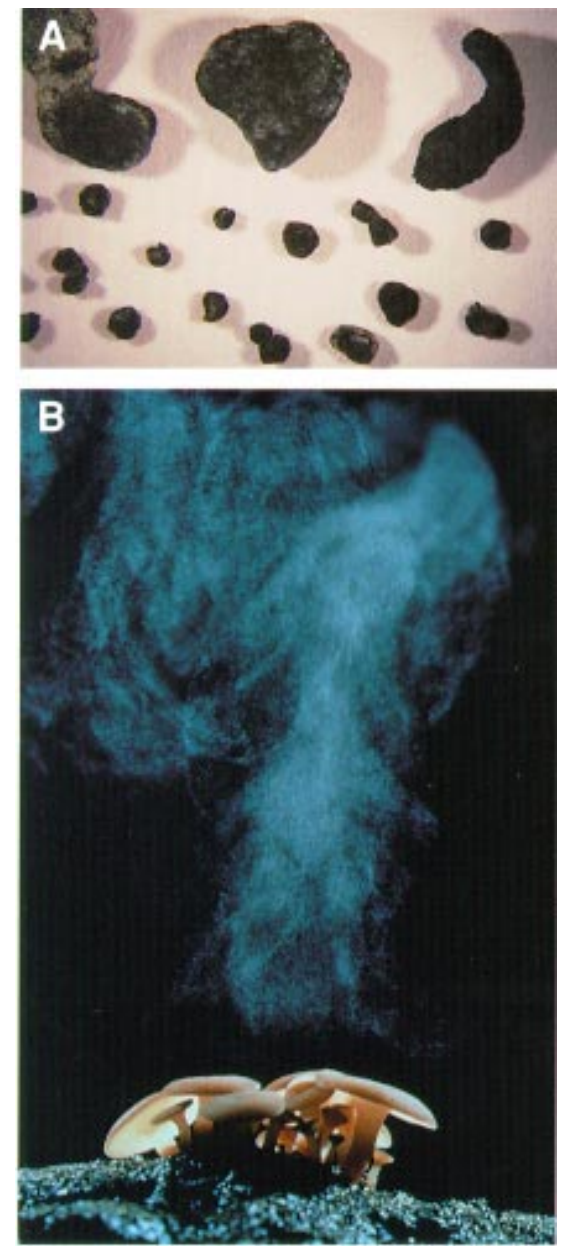

Fig. 3. (A) Large, irregular S. sclerotiorum sclerotia (top, magnified $\times 8$ ) and small, mostly circular $S$. minor sclerotia (bottom, magnified $\times 8$ ). (B) A carpogenically germinated sclerotium of $S$. sclerotiorum with a number of apothecia and the ascospore cloud emanating from them. Reprinted with permission from the American Phytopathological Society, St. Paul, MN. tissue depends on the type of inoculum, the nutrient status of the fungus, and environmental conditions. De Bary observed that Sclerotinia requires external nutrients for successful infection (39). S. sclerotiorum produces a wide array of degradative, lytic enzymes, such as endo- and exopectinases, cellulases, hemicellulases, and proteases, that are believed to facilitate colonization and host cell wall degradation (39). The role of oxalic acid in the infection process is well documented $(24,40,49)$. Even before the cause-effect relationship of germ theory was an accepted scientific concept, De Bary in 1886 observed an association between the production of oxalic acid in carrots and infection by $S$. sclerotiorum (39). Recent studies (24) with oxalic aciddeficient mutants of $S$. sclerotiorum have implicated oxalic acid as a pathogenicity determinant. While the mutants were identical to their wild-type counterparts except for the production of oxalic acid, they were unable to cause infection or to form sclerotia. Despite possessing a full complement of degradative enzymes, including polygalacturonase, pectin methylesterase, and cellulase, the mutants were all nonpathogenic, suggesting that these enzymes were important for tissue maceration but not sufficient for disease establishment
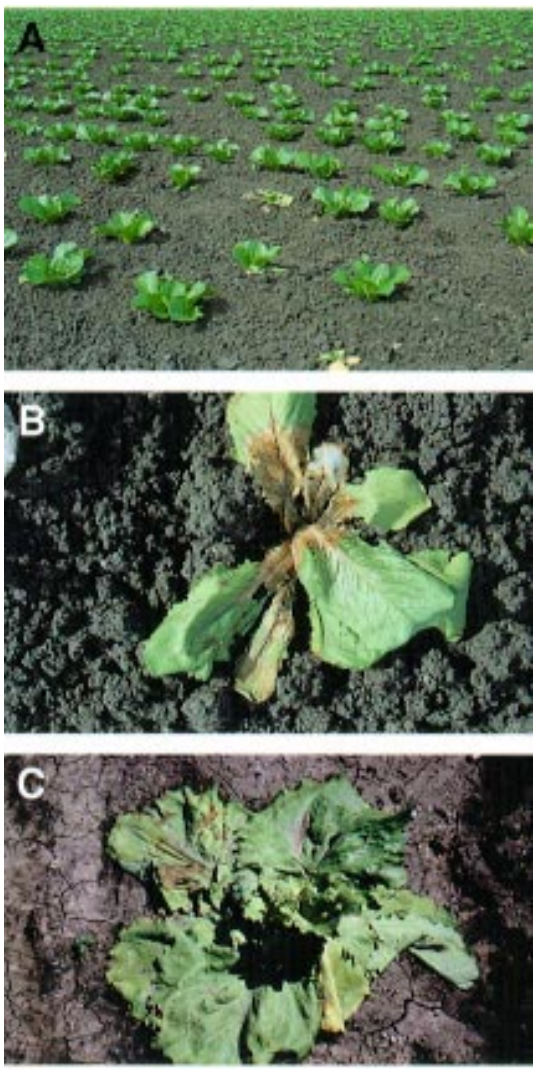

Fig. 4. (A) Lettuce drop caused by Sclerotinia sclerotiorum via mycelial contact at the rosette stage. (B) Watersoaked and rotted crown of an infected lettuce plant. (C) Lettuce drop caused by S. minor at rosette stage. Reprinted with permission from the American Phytopathological Society.
(24). Oxalic acid produced by the pathogen, upon successful entry into the host, reduces the $\mathrm{pH}$ of the host tissue, which decreases host cell viability and therefore its ability to respond to pathogen invasion (40). Oxalic acid may also sequester $\mathrm{Ca}^{2+}$ from calcium pectate of the host cell wall, favoring polygalacturonase activity (49). Additionally, calcium oxalate crystals may occlude xylem vessels, leading to wilt symptoms (49).

Recent studies (21) have ascribed yet another role for oxalic acid in pathogenesis. The reduced $\mathrm{pH}$ in host tissue, as a
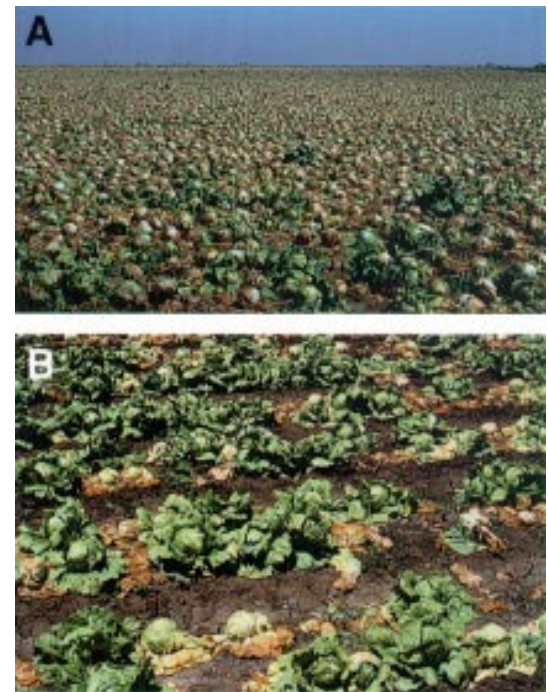

Fig. 5. (A) Plants killed by airborne Sclerotinia sclerotiorum ascospores. (B) Lettuce drop at crop maturity.
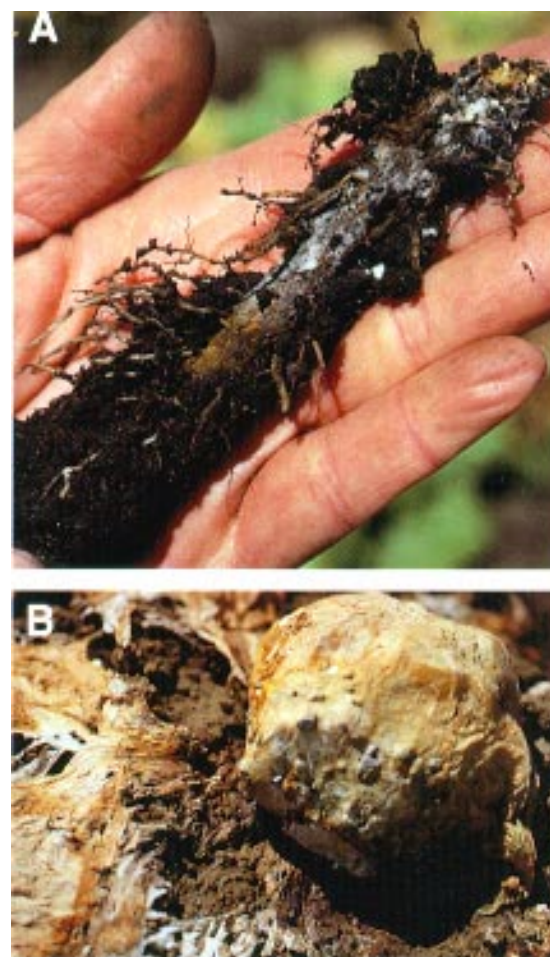

Fig. 6. (A) Extensively colonized taproot of a lettuce plant converted into sclerotia. (B) A close-up of a degenerated lettuce plant with abundant sclerotia. 
result of production of oxalic acid by $S$. sclerotiorum, also inhibits enzymes, such as $o$-diphenol oxidase, that are implicated in host defense mechanisms. Thus, the inhibition of $o$-diphenol oxidase by oxalic acid distinctly enhances the pathogenicity of $S$. sclerotiorum (21).

Disease cycle and epidemiology. The characteristics that separate the two species of Sclerotinia also significantly impact the mode of infection of lettuce plants. The generalized disease cycles for both species are presented in Figure 7.

Both species survive in soil mainly as sclerotia for up to 8 to 10 years $(4,13)$, but they may also survive as active mycelium in living or dead plants (16). Survival of sclerotia of both species is affected by the location of sclerotia along the soil profile, duration of burial, soil moisture, and soil temperature. The viability of sclerotia is reduced over time and with increasing soil moisture. In saturated soil, sclerotia of $S$. minor disintegrate or fail to germinate within 8 weeks (32). Thermal inactivation of $S$. minor sclerotia occurs at $40^{\circ} \mathrm{C}$ within $39 \mathrm{~h}$, at $45^{\circ} \mathrm{C}$ within $6 \mathrm{~h}$, and at $50^{\circ} \mathrm{C}$ within $2 \mathrm{~h}$ (4). S. sclerotiorum sclerotia survive well for at least 15 months at depths of up to $30 \mathrm{~cm}$ (3). S. sclerotiorum sclerotia can survive up to 7 years, even when buried, under certain conditions. Nearly $90 \%$ of S. sclerotiorum sclerotia in the soil are thermally inactivated at $35^{\circ} \mathrm{C}$

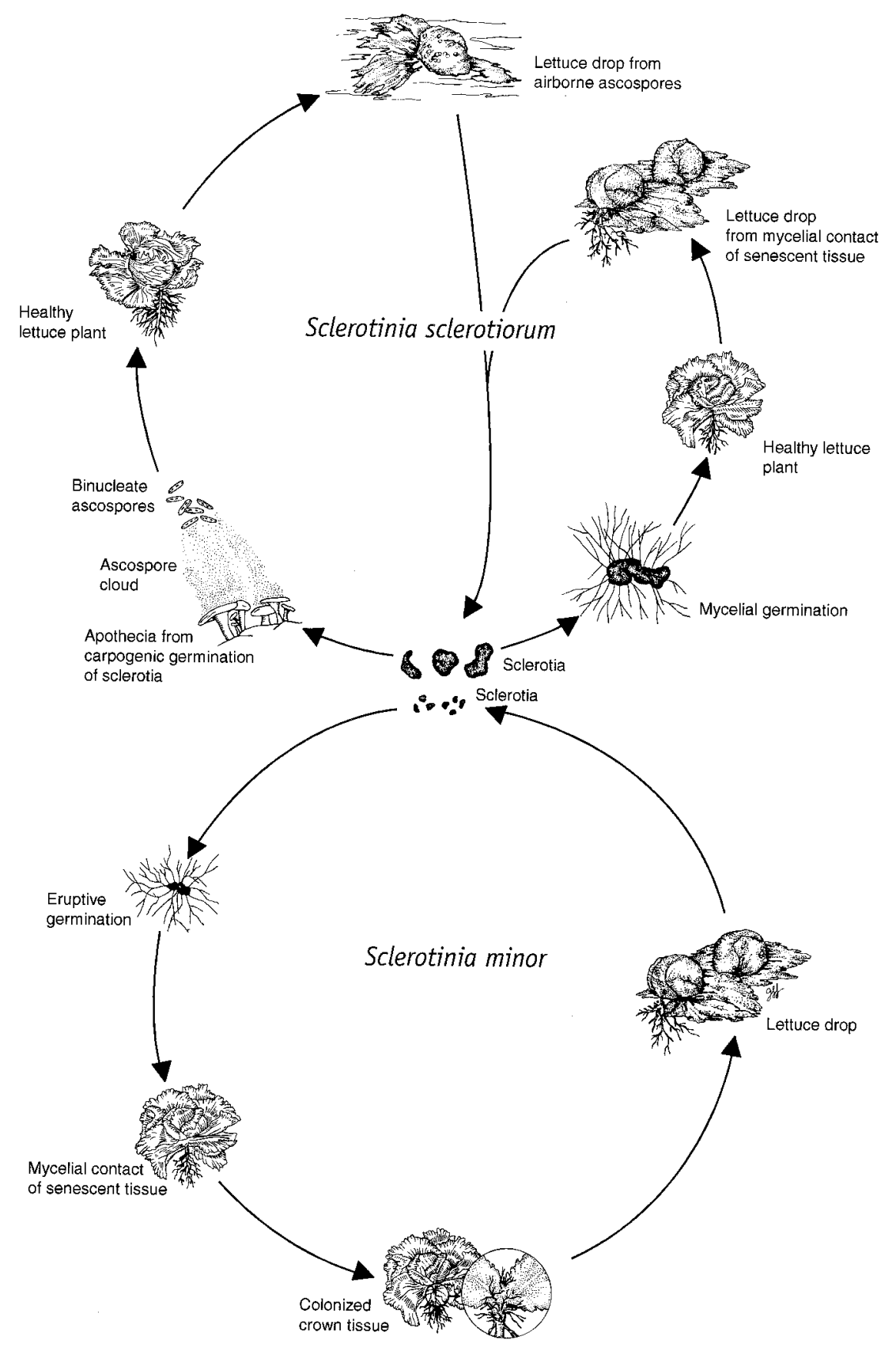

Fig. 7. Disease cycles of Sclerotinia sclerotiorum and S. minor on lettuce.

(13). Survival of $S$. minor sclerotia is also reduced in soils with heavy infestations of the dark-winged fungus gnat (Bradysia coprophila Lintner). Larvae of these gnats damage sclerotia directly by feeding and indirectly by increasing the colonization of damaged sclerotia by soil mycoparasites (25).

Germination of sclerotia in both species is negatively affected by the quantitative and qualitative microfloral content in the soil $(1,16,63)$. S. sclerotiorum sclerotia below the soil surface germinate carpogenically after a period of chilling $\left(4^{\circ} \mathrm{C}\right)$ at soil moisture near saturation for 2 or more weeks by forming apothecia that produce and release millions of airborne ascospores (Fig. 3B) (20,35). Preconditioning by constant rinsing under running water enhances the production of apothecia in the laboratory (20). Greater numbers of apothecia per sclerotium are produced when the sclerotia are located in the top $5 \mathrm{~cm}$ of the soil profile than in deeper soil profiles (47). The formation of apothecia is strongly photodependent, and light intensity greater than $58.1 \mu \mathrm{E} \cdot \mathrm{s}^{-1} \cdot \mathrm{m}^{-2}$ favors the development of apothecia (35). Greater numbers of apothecia per sclerotium are produced by larger sclerotia than by smaller ones (13). Optimal temperatures of 8 to $16^{\circ} \mathrm{C}$ are particularly favorable for the formation of apothecial initials and ultimately apothecia. Conditions for the carpogenic germination of sclerotia of $S$. minor are rare in nature (28) and have not been quantified precisely.

Eruptive germination of $S$. minor sclerotia is affected by the moisture status of sclerotia. Sclerotia produced on the host tissues do not germinate well because of their high moisture content. They have to dry somewhat before a majority of them can germinate (51). Soil moisture and temperature significantly affect eruptive germination in $S$. minor. Germination of sclerotia occurs when soil matric potential is between $-0.03 \mathrm{MPa}$ and $-1.5 \mathrm{MPa}$, with an optimum at $-0.03 \mathrm{MPa}$ (2). Germination and mycelial growth occur between 6 and $30^{\circ} \mathrm{C}$, with an optimum at $18^{\circ} \mathrm{C}(33)$.

Infection by either species can occur at any crop growth stage, but economic losses occur most often during crop maturity. The ascospores, released over a period of 2 to 3 weeks, are dispersed throughout the lettuce field and adjacent fields by wind. After landing on senescing or dead lettuce leaves, ascospores in the presence of free water on the leaf for $48 \mathrm{~h}$ or more germinate to produce hyphae that infect and kill the plant by girdling the root-crown area (50). Plants infected by airborne ascospores form sclerotia on the aerial parts of the plants (Figs. 6B and 7). Mycelial infection from eruptively germinating (Fig. 8A) $S$. sclerotiorum can also occur, but infection of plants by this mode in commercial fields is uncommon (50). Because of the requirements for specific conditions to 
"prime" the sclerotia to produce apothecia and ascospore release, lettuce drop caused by $S$. sclerotiorum is sporadic and unpredictable.

In contrast, $S$. minor sclerotia seldom produce apothecia, and infections are caused by eruptive germination of sclerotia (Figs. 7 and 8B). Sclerotia located within 2 $\mathrm{cm}$ of the taproot and $8 \mathrm{~cm}$ of the soil surface produce masses of hyphae that infect nearby roots, stems, and senescent leaves (32) (Fig. 7). Infection of lettuce plants by $S$. minor can also occur over a wide temperature range $\left(6\right.$ to $24^{\circ} \mathrm{C}$ ), with an optimum at $18^{\circ} \mathrm{C}$ (33). Plant-to-plant spread occurs occasionally by mycelial contact. Large numbers of sclerotia are formed on the crown and subterranean parts of the infected lettuce plant (Figs. 6A and 7). The sclerotia of both species are returned to the soil when the lettuce residue is disked under after harvest.

Because only sclerotia of $S$. minor located within $2 \mathrm{~cm}$ of the taproot and $8 \mathrm{~cm}$ of the soil surface are capable of infecting lettuce plants, Grogan et. al. (26) coined the terms competence distance and competence depth to describe these two factors. The total volume of soil encompassing the maximum depth and distance from which a sclerotium can infect lettuce plants, referred to as the competence volume for $S$. minor, was determined to be $100 \mathrm{~cm}^{3}$ (26). The concept of competence volume has significant implications for soil sampling to determine the inoculum density. Soil sampling techniques to incorporate the concept of competence volume of soilborne propagules require assaying the soil samples in their entirety. We have therefore custom-designed soil samplers to obtain cores of $100 \mathrm{~cm}^{3}$.

\section{Disease Management}

Management of lettuce drop includes chemical, cultural, biological, and physical control methods. Currently, no single management technique provides satisfactory levels of control, so growers have integrated several methods. Differences in epidemiology of the disease caused by the two species of Sclerotinia (50) necessitate different methods of control. The involvement of airborne ascospores in S. sclerotiorum makes it more difficult to manage lettuce drop caused by this species.

Chemical control. Until the mid-1970s, only one fungicide, 2,6-dichloro-4-nitroaniline (DCNA) was registered for the control of lettuce drop. Marcum et. al. (41) determined DCNA should be applied immediately after thinning for best control of lettuce drop. Subsequent post-thinning applications do not provide satisfactory control.

Other fungicides, such as benomyl, have given mixed results. Post-thinning applications of benomyl failed to control lettuce drop caused by $S$. minor in California (41) and New Zealand (29). However, in Israel, benomyl reduced the number of sclerotiaproducing apothecia and as a result, reduced the incidence of lettuce drop caused by $S$. sclerotiorum (11). Currently, benomyl does not have a lettuce label in the United States.

The advent of cyclic imides and the registration of fungicides such as iprodione (3-(3,5-dichlorophenyl)- $N$-isopropyl-2,4- dioxoimidazolidine-1-carboxamide) and vinclozolin (RS)-3-(3,5-dichlorophenyl)-5methyl-5-vinyl-1,3-oxazolidine-2,4-dione), sprayed over the bed and at the base of plants immediately after lettuce thinning, dramatically improved lettuce drop control. These were the most widely used fungicides for lettuce drop control until the late 1980s. The ability of iprodione and vinclozolin to control lettuce drop was shortlived. Growers in France reported a dramatic failure of iprodione and vinclozolin to control lettuce drop (42). The lack of control is related to rapid degradation in soils repeatedly treated with these fungicides. In a study involving 33 soils from commercial fields, $90 \%$ of iprodione applied to the soils with an extensive pretreatment history degraded within 5 days, compared with more than 90 days in previously untreated soils (64). Enhanced degradation of iprodione and vinclozolin is exacerbated by both $\mathrm{pH}$ and soil microbial population (64). Little degradation of either of these fungicides occurred at $\mathrm{pH} 4.3$ or 5.0, and degradation at $\mathrm{pH} 5.7$ was slower than at $\mathrm{pH} 6.5$ in soil with or without a history of iprodione or vinclozolin usage. In soil with $\mathrm{pH} 6.5$, the half-life following the first, second, and third applications was 30,12 , and 4 days for iprodione and 30, 22, and 7 days for vinclozolin. Studies in France (9) confirmed these re-
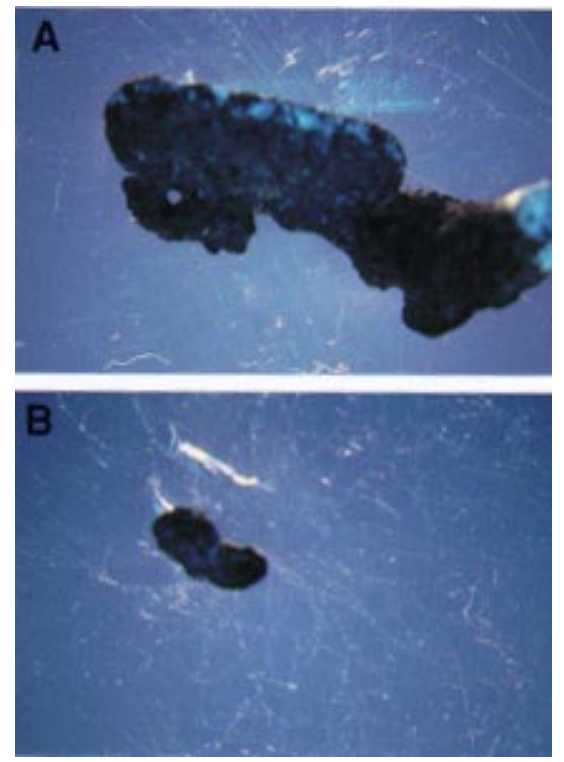

Fig. 8. (A) Eruptively germinated sclerotium of Sclerotinia sclerotiorum. (B) Eruptively germinated sclerotium of $S$. minor. sults but also demonstrated that the enhanced degradation of iprodione and vinclozolin could be reversed by soil solarization, thus implicating the involvement of soil microbes in the degradation.

In recent years, losses from lettuce drop have been severe in California despite fungicide applications. Iprodione or vinclozolin resistance was not detected in field populations of $S$. minor, but resistance could be readily induced in vitro. The iprodione-resistant strains exhibited cross-resistance against vinclozolin and vice versa. Nearly all resistant strains became avirulent 10 months after selection in vitro. Fungicide efficacy on wild-type $S$. minor population in commercial fields indicated that fungicide resistance was not the cause of control failure in coastal California fields. Application of fungicides at a less than optimal time and enhanced degradation of fungicides in California soils may explain the recent lack of control observed in coastal California (30).

Application of metham-sodium, either by sprinklers (11) or through drip irrigation, has provided encouraging results. The efficacy of metham-sodium is affected by penetration into soil, which is affected both by the soil structure and temperature. Because the toxicity of metham-sodium to the pathogens is greatest at $35^{\circ} \mathrm{C}(12)$, the use of this chemical for lettuce drop control has not gained wide acceptance by lettuce growers in California and elsewhere. Currently registered fungicides provide less than satisfactory control of lettuce drop caused by either Sclerotinia spp. Growers are therefore integrating several alternative methods along with fungicides for satisfactory management of lettuce drop.

Deep plowing and roguing. Because survival of sclerotia decreases with time
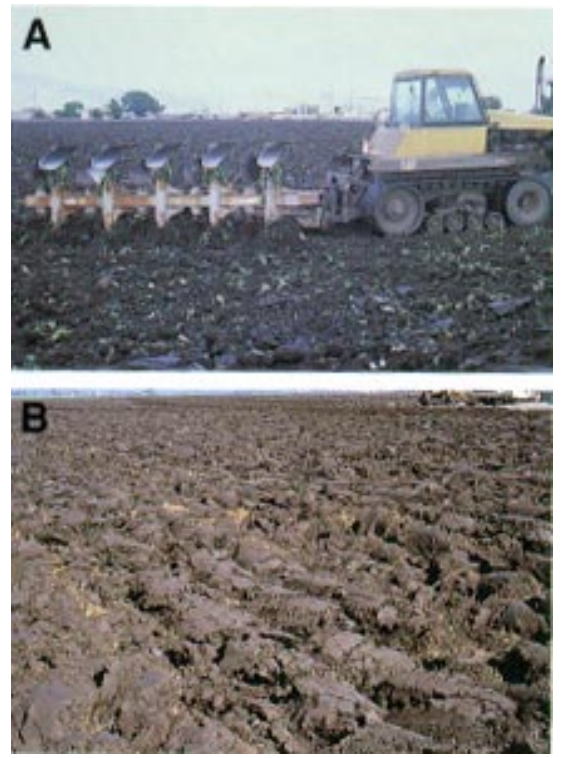

Fig. 9. (A) A Wilcox plow adapted for deep plowing. (B) Large clods formed as a result of deep plowing in a commercial field. 
and depth of burial, movement of sclerotia to depths greater than $10 \mathrm{~cm}$ will prevent lettuce drop infections $(26,32)$. Factors such as soil temperature, $\mathrm{O}_{2}, \mathrm{CO}_{2}$, and ethylene concentrations change with soil depth and may influence survival. However, Imolehin and Grogan (31) concluded that these factors are usually not limiting to the survival of $S$. minor sclerotia. The increased mortality of sclerotia at greater depths occurred because of the colonization of sclerotia by antagonistic fungi. These findings led to the development of deep plowing as a disease management practice to bury sclerotia located in the upper soil profile. Because S. sclerotiorum also has an airborne phase, deep plowing was not expected to be as successful as with $S$. minor. A moldboard plow was specifically designed for deep plowing (Fig. 9A), and the growers immediately adopted this technique in 1985. The initial euphoria soon gave way to disappointment as growers in the Salinas Valley in California with high inoculum densities observed that the level of lettuce drop control from deep plowing did not justify its cost.

Disease incidence was often greater in the second crop after deep plowing than prior to deep plowing. The spatial distribution of sclerotia changed from a highly aggregated pattern prior to deep plowing to a more uni-
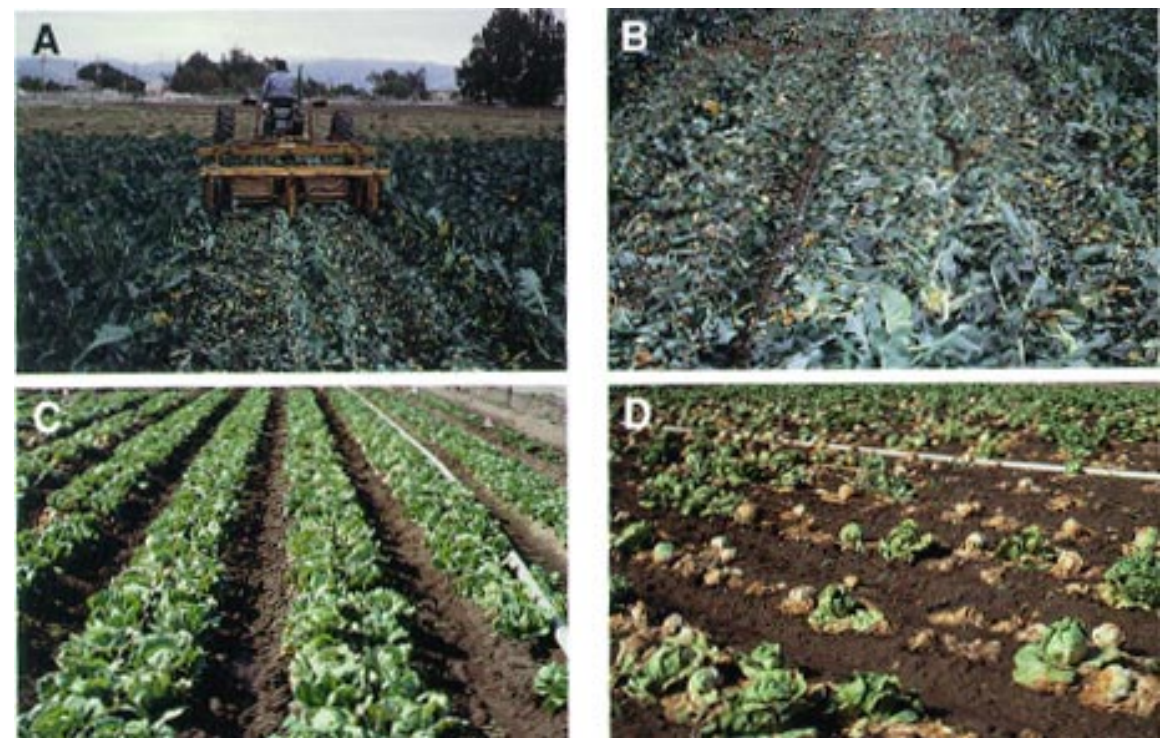

Fig. 10. (A) Broccoli being chopped by a Marvin incorporator. (B) Residue on top of the planting beds immediately after chopping. (C) Low incidence of lettuce drop following incorporation of previous broccoli crop residue. (D) Severe incidence of lettuce drop under continuous lettuce production.
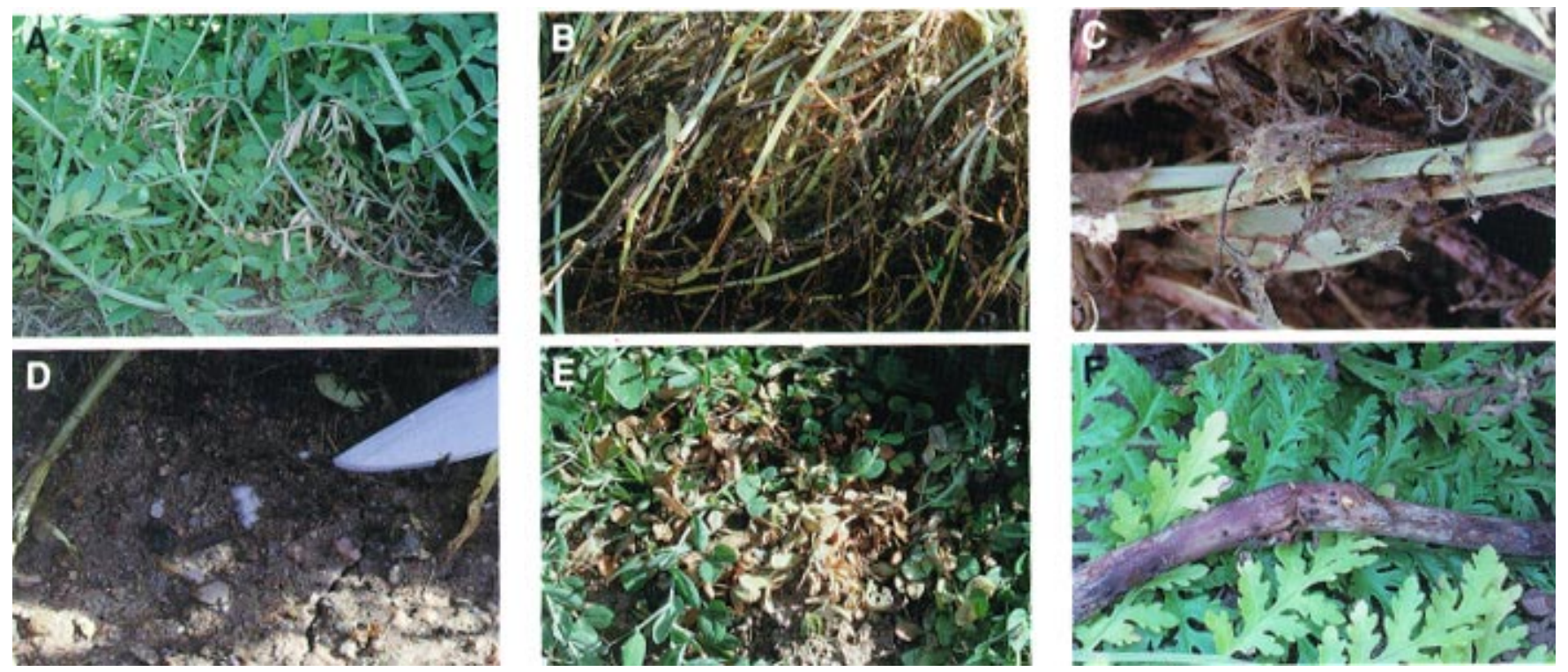

Fig. 11. (A) Early symptoms of Sclerotinia minor colonization of Vicia benghalensis stems. (B) Heavy infection of $V$. benghalensis by $S$. minor and the resultant defoliation. (C) $S$. minor sclerotia on colonized $V$. benghalensis stems. (D) Eruptive germination of sclerotia in a plot cover-cropped with V. benghalensis. (E) Pisum sativum subsp. arvense infected by Sclerotinia minor. (F) Sclerotia on infected stems of Phacelia tanacetifolia. 
use of rotation as an agronomic tool. Pathogens such as S. minor and S. sclerotiorum are not easily managed by crop rotations because of their wide host range. Recently, however, broccoli (Brassica oleracea L. var. botrytis L.) reduced the number of Verticillium dahliae microsclerotia in soil and Verticillium wilt on cauliflower (60). Because $S$. minor also produces sclerotia, we evaluated rotations of lettuce with broccoli to reduce $S$. minor sclerotia and lettuce drop incidence. The 2year sequence of treatments in this experiment included: (i) lettuce-lettuce-lettucelettuce; (ii) broccoli-lettuce-broccoli-lettuce; (iii) broccoli-broccoli-lettuce-lettuce; and (iv) fallow-lettuce-fallow-lettuce. To ensure the uniform availability of inoculum, all lettuce plants were individually inoculated with a mixture of myceliuminfested rye seed and $S$. minor sclerotia when the experiment was initiated in the spring of 1996. Infection of lettuce and broccoli by $S$. minor was recorded weekly. The pathogen failed to infect broccoli. At maturity, crops in the corresponding plots were chopped using a Marvin incorporator (Fig. 10A and B), and after 2 days, the residue was incorporated to a depth of 15 to $20 \mathrm{~cm}$ with the same equipment. One month after residue incorporation, the plots were tilled and beds were shaped for planting the next crop in each treatment. After completing the entire cropping sequence, we observed that, not only were the numbers of sclerotia in soil reduced after the broccoli residue was incorporated each season, but also the incidence of drop on the subsequent lettuce crops was significantly lower where lettuce followed broccoli than with continuous lettuce (Fig. $10 \mathrm{C}$ and D) or fallow followed by lettuce treatments (K. V. Subbarao, J. C. Hubbard, S. T. Koike, K. F. Schulbach, unpublished data). Based on the results of this study, a number of growers have already tested rotations of lettuce with broccoli and have obtained similar results. For the first time, crop rotation could become a viable option to manage lettuce drop.

Because soil organic matter is important to soil fertility and productivity, increasing numbers of growers in the Salinas Valley have expressed interest in planting winter cover crops or green manure crops to alleviate decreased soil organic matter, poor soil fertility, poor soil structure, and nitrate loss from leaching $(37,38)$. Among the cover crops being tested, Phacelia (Phacelia tanacetifolia Benth.), purple vetch (Vicia benghalensis L.), Lana woollypod vetch ( $V$. dasycarpa Ten.), and Austrian winter pea (Pisum sativum L. subsp. arvense) are also hosts of $S$. minor (Fig. 11A to F) $(19,37)$. Lettuce crops following these cover crops have significantly higher levels of lettuce drop compared with plots that were left fallow during the winter (19,37). The risk of increased lettuce drop in fields previously planted to the above cover crops serves as a deterrent to their adaptation by growers.

Biocontrol. Currently, no efficacious biocontrol for either species of Sclerotinia is available for commercial application. A number of biocontrol agents, including Coniothyrium minitans, Gliocladium virens, Sporidesmium sclerotivorum, Talaromyces flavus, and Trichoderma harzianum, have been tested. The best characterized biocontrol agents are Sporidesmium sclerotivorum on $S$. minor (5-8), and $C$. minitans on $S$. sclerotiorum $(22,43)$. Sporidesmium sclerotivorum is widely distributed in agricultural soils of the United States and is an obligate parasite of sclerotial fungi, including $S$. minor and $S$. sclerotiorum. In extensive field tests in Beltsville, Maryland, the Sporidesmium sclerotivorum significantly reduced inoculum density of $S$. minor, but lettuce drop control was modest at best (6). The ability of Sporidesmium sclerotivorum to control $S$. minor in all soil types is questionable. Efficacy of Sporidesmium sclerotivorum in California lettuce fields has been disap- pointing (36; S. T. Koike, personal communication). One reason for control failure is the neutral to alkaline $\mathrm{pH}$ of California lettuce fields. Growers in coastal California generally lime fields to avoid clubroot on cruciferous crops, which increases the soil $\mathrm{pH}$ to 7.0 or above. The optimum $\mathrm{pH}$ range for the growth of Sporidesmium sclerotivorum is 4.5 to 5.5 (5). Failure to control lettuce drop in acidic soils is not well understood. Biocontrol for lettuce drop is also incompatible with chemical control because of the detrimental effects of fungicides on the biocontrol agent (8). In addition to soil conditions in California that are unsuitable for maximum efficacy, the cost of using Sporidesmium sclerotivorum (6) discourages its use.

Much of the information on $C$. minitans has come from studies on $S$. sclerotiorum infecting canola (Brassica rapa L.) and sunflower (Helianthus annuus L.). Although the ability of $C$. minitans to reduce the viability of $S$. sclerotiorum sclerotia and apothecial production in vitro is well documented $(22,43)$, the biocontrol agent failed to reduce disease on canola in the field. Factors affecting efficacy in the field need to be studied before biocontrol for diseases caused by Sclerotinia spp. is realized. Recently, using hypovirulent strains of $S$. minor for biocontrol has been suggested $(14,44)$, but the practicality of this approach remains to be demonstrated.

Irrigation methods. Lettuce production in coastal California occurs under different types of irrigation. Traditionally, furrow irrigation was used because of the ease of operation, but water use is high and inefficient, and salt accumulation is a major problem. In the late 1960 s, growers adopted sprinkler irrigation for optimal seedling emergence and plant stand establishment (10). Sprinklers offered many advantages for lettuce production, such as decreased salt accumulation near seed rows, rapid and uniform application of water, higher and more uniform seed

Table 2. Lettuce drop incidence at harvest, number of marketable heads, and total yield on two lettuce cultivars in subsurface drip- and furrowirrigated plots during 1993 to 1995 in the Salinas Valley, CA

\begin{tabular}{|c|c|c|c|c|c|}
\hline Year and season & Cultivar & Irrigation & $\operatorname{Drop}^{w}(\%)$ & $\mathbf{N M H}^{\mathbf{x}}$ & $\begin{array}{l}\text { Yield } \\
(\mathbf{k g})^{\mathrm{y}}\end{array}$ \\
\hline \multirow[t]{2}{*}{1993 spring $^{\mathrm{Z}}$} & Salinas & Drip & $21.6 \mathrm{~b}$ & $28.8 \mathrm{a}$ & $15.7 \mathrm{a}$ \\
\hline & & Furrow & $41.8 \mathrm{a}$ & $21.2 \mathrm{~b}$ & $9.5 \mathrm{~b}$ \\
\hline \multirow{2}{*}{1993 fall } & Misty Day & Drip & $31.4 \mathrm{~b}$ & $22.3 \mathrm{a}$ & $10.1 \mathrm{a}$ \\
\hline & & Furrow & $59.8 \mathrm{a}$ & $13.6 \mathrm{~b}$ & $6.7 \mathrm{~b}$ \\
\hline \multirow[t]{2}{*}{1994 spring } & Salinas & Drip & $3.3 \mathrm{~b}$ & $38.3 \mathrm{a}$ & $21.9 \mathrm{a}$ \\
\hline & & Furrow & $33.8 \mathrm{a}$ & $24.3 \mathrm{~b}$ & $14.1 \mathrm{~b}$ \\
\hline \multirow[t]{2}{*}{1995 spring } & Salinas & Drip & $10.3 \mathrm{~b}$ & $42.3 \mathrm{a}$ & $31.0 \mathrm{a}$ \\
\hline & & Furrow & $27.4 \mathrm{a}$ & $37.8 \mathrm{~b}$ & $25.0 \mathrm{~b}$ \\
\hline \multirow[t]{2}{*}{1995 fall } & Misty Day & Drip & $15.1 \mathrm{~b}$ & $19.0 \mathrm{a}$ & $9.4 \mathrm{a}$ \\
\hline & & Furrow & $41.8 \mathrm{a}$ & $8.7 \mathrm{~b}$ & $4.1 \mathrm{~b}$ \\
\hline
\end{tabular}

${ }^{\mathrm{v}}$ Modified and reprinted with permission from reference 61 .

${ }^{\mathrm{w}}$ Mean lettuce drop incidence in the central $24 \mathrm{~m}^{2}$ area on the middle four beds of each treatment plot.

${ }^{x}$ Mean number of marketable lettuce heads in the central $24 \mathrm{~m}^{2}$ area on the middle four beds of each treatment plot.

${ }^{y}$ Mean weight of the total marketable heads.

${ }^{\mathrm{z}}$ Within each column and season, the numbers followed by the same letter are not significantly $(P>0.05)$ different according to the LSD test. 
emergence, more efficient use of water, and higher yields. With the potential shortage of available water for vegetable production, and the need for preventing contamination of groundwater by fertilizers and pesticides, a large number of growers are adopting subsurface drip irrigation. Subsurface drip irrigation requires about half the water needed by furrow and sprinkler systems and, since fertilizers can be applied directly to the root zone, fertilizer efficiency is increased while $\mathrm{NO}_{3}{ }^{-}$leaching is decreased. Initial installation of subsurface drip irrigation is expensive, but once the system is in place, operating costs are low.

A comparative study of furrow and subsurface drip irrigation on diseases and yield of lettuce revealed a significant reduction in the incidence of lettuce drop (Fig. 12A and B) and increased yield under subsurface drip irrigation (61; Table 2). The control achieved through drip irrigation was superior to furrow irrigation plus fungicide application. More $S$. minor sclerotia were added to the soil after each lettuce crop under furrow irrigation compared with subsurface drip irrigation. Populations
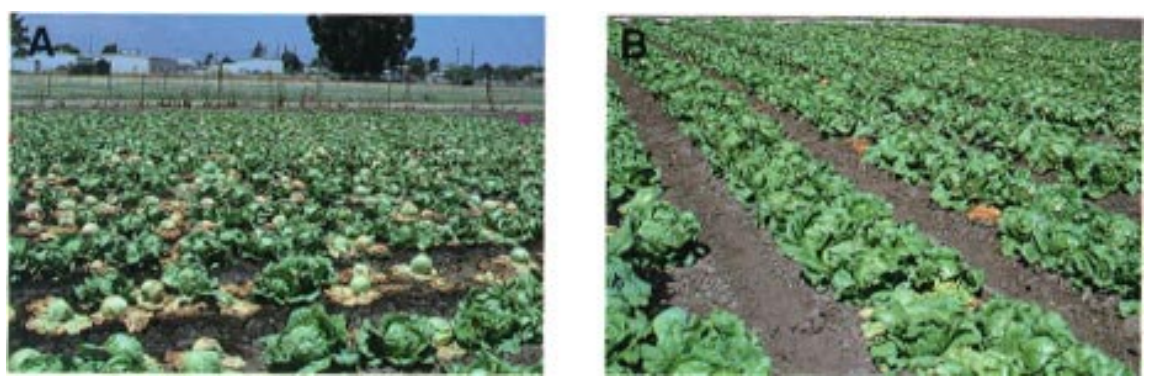

Fig. 12. (A) Incidence of lettuce drop under furrow irrigation. (B) Incidence of lettuce drop under subsurface drip irrigation.

Table 3. Reaction of select germ plasm accessions for "slow-dying" resistance to Sclerotinia minor

\begin{tabular}{|c|c|c|c|}
\hline PI number or cultivar ${ }^{y}$ & Incidence (\%) & Mode $(\text { days })^{\mathrm{z}}$ & Range (days) \\
\hline 250020 & 20 & 6 & $3-8$ \\
\hline 169513 & 20 & 8 & $1-15$ \\
\hline 171665 & 20 & 8 & $6-10$ \\
\hline 171676 & 40 & 8 & $2-14$ \\
\hline 172914 & 60 & 6 & $3-12$ \\
\hline 251246 & 10 & 6 & $6-6$ \\
\hline 140295 & 0 & $\ldots$ & \\
\hline 171666 & 10 & 5 & $5-5$ \\
\hline 171669 & 10 & 11 & $11-11$ \\
\hline 171671 & 10 & 4 & $4-4$ \\
\hline 172920 & 50 & 7 & $1-13$ \\
\hline 174225 & 40 & 7 & $2-14$ \\
\hline 174229 & 20 & 6 & $3-8$ \\
\hline 175735 & 50 & 6 & $0-11$ \\
\hline 176578 & 60 & 6 & $2-21$ \\
\hline $\begin{array}{l}\text { Batavia Reine de Glacé } \\
\text { (control) }\end{array}$ & 80 & 1 & $0-4$ \\
\hline Salinas (control) & 60 & 1 & $0-6$ \\
\hline
\end{tabular}

y One hundred twenty germ plasm accessions and cultivars were screened. Twenty plants from each accession were individually inoculated. The reactions of only the promising lines are presented here along with the susceptible checks.

${ }^{\mathrm{z}}$ Days after the appearance of mycelium at the crown when greater than $60 \%$ of the plants in the corresponding germ plasm accession died.

of sclerotia increased about fivefold after 3 ears of conventional tillage under furrow Untion than with subsurface drip irrigation. Under subsurface drip irrigation, the distriwere changed litle by minimu tilage practices (58). The suppression of lettuce drop under subsurface drip compared with furrow irrigation is attributed to differen(to changes in the culturable soil fungal, actinomycete, or bacterial populations (10). A random survey of commercial fields under subsurface drip and furrow irrigation in the lettuce drop under subsurface drip irrigation. Subsurface drip irrigation is a valuable lettuce drop management strategy in areas with no significant amounts of rainuring lettuce cultivation. vars offer the most predictable, convenic and least expensive option for managing lettuce drop. However, developing resistance to drop in lettuce has been difficult and slow. Currently, no resistant commercial cultivars are available. Resistance to

(1)
caus - residue is left after a cast to air Valley contribute to air pollution, burning is not an acceptable management practice.

\section{Outlook}

Despite the voluminous literature on lettuce drop caused by both $S$. minor and $S$. sclerotiorum, the disease continues to be a major production constraint in most lettuce producing areas, and particularly in California. Research has documented the biological and environmental factors that affect survival, germination, and the ability of Sclerotinia spp. to cause lettuce drop under artificially controlled conditions. The conclusions drawn from these studies, however, have not developed into effective and consistent disease management technologies. While subsurface drip irrigation provides economical control of lettuce drop and obviates the need for fungicide use, this type of irrigation technology is expensive and cannot be used in areas that receive rainfall during lettuce cultivation. 
Therefore, the identification and development of resistance in lettuce to drop would certainly be considered a Holy Grail. Traditional breeding efforts to date have not resulted in drop-resistant lettuce cultivars. Success in resistance breeding is likely to come from two approaches. First, slow-dying resistance provides a powerful tool to assess resistance to $S$. minor and identify sources of resistance. It is important to determine the heritability of this trait before breeding efforts are directed toward incorporating this characteristic into horticulturally superior backgrounds. Second, for the less specialized necrotrophs such as Sclerotinia spp. that have been difficult to control by traditional breeding, success may come from the use of transgenes. Several potentially useful transgenes have already been introduced into lettuce. Currently, however, a ratelimiting step to the deployment of transgenes in lettuce is the loss of phenotype in later generations (46). Once the mechanism underlying this loss of phenotype is understood, rapid progress in breeding resistance to lettuce drop is likely. Until resistant cultivars are available, management of this disease should depend on rotations with crops that actively decrease the number of soilborne sclerotia and integration of other available techniques.

\section{Acknowledgments}

I thank the California Iceberg Lettuce Research Advisory Board that has supported the various research projects from which results have been gleaned for this article along with several growers for providing field sites for data collection. I am also grateful to J. Hubbard, S. Koike, and K. Schulbach for cooperation in the various projects. I thankfully acknowledge the presubmission reviews of C. Bull, S. Fennimore, S. Koike, and K. Shetty. The slides from S. Koike for Figures 9 and 11, and the artwork of J. Lockwood, are gratefully acknowledged. I am grateful to the anonymous reviewers for their criticisms and suggestions on the manuscript.

\section{Literature Cited}

1. Abawi, G. S., Grogan, R. G., and Duniway, J. M. 1985. Effect of water potential on survival of sclerotia of Sclerotinia minor in two California soils. Phytopathology 75:217-221.

2. Abawi, G. S., Robinson, R. W., Cobb, A. C., and Shail, J. W. 1980. Reaction of lettuce germ plasm to artificial inoculation with Sclerotinia minor under greenhouse conditions. Plant Dis. 64:668-671.

3. Adams, P. B. 1975. Factors affecting survival of Sclerotinia sclerotiorum in soil. Plant Dis. Rep. 59:599-603.

4. Adams, P. B. 1987. Effects of soil temperature, moisture, and depth on survival and activity of Sclerotinia minor, Sclerotium cepivorum, and Sporidesmium sclerotivorum. Plant Dis. 71:170-174.

5. Adams, P. B. 1990. The potential of mycoparasites for biological control of plant diseases. Annu. Rev. Phytopathol. 28:59-72.

6. Adams, P. B., and Fravel, D. R. 1990. Economical biological control of Sclerotinia lettuce drop by Sporidesmium sclerotivorum. Phytopathology 80:1120-1124.

7. Adams, P. B., and Tate, C. J. 1976. Mycelial germination of sclerotia of Sclerotinia sclerotiorum on soil. Plant Dis. Rep. 60:515-518.
8. Adams, P. B., and Wong, J. A.-L. 1991. The effect of chemical pesticides on the infection of sclerotia of Sclerotinia minor by the biocontrol agent Sporidesmium sclerotivorum. Phytopathology 81:1340-1343.

9. Alfizar, A., Martin, C., and Davet, P. 1992. Appearance, persistence, and potential control of enhanced biodegradation of iprodione and vinclozolin in the field. Agronomie 12:733-738.

10. Bell, A. A., Liu, L., Reidy, B., Davis, R. M., and Subbarao, K. V. 1998. Mechanisms of subsurface drip irrigation-mediated suppression of lettuce drop caused by Sclerotinia minor. Phytopathology 88:252-259.

11. Ben-Yephet, Y., Bitton, S., and Greenberger, A. 1986. Control of lettuce drop disease, caused by Sclerotinia sclerotiorum, with metham-sodium soil treatment and foliar application of benomyl. Plant Pathol. 35:146-151.

12. Ben-Yephet, Y., and Frank, Z. R. 1985. Effect of soil structure on penetration by methamsodium and of temperature on concentrations required to kill soilborne pathogens. Phytopathology 75:403-406.

13. Ben-Yephet, Y., Genizi, A., and Siti, E. 1993. Sclerotial survival and apothecial production by Sclerotinia sclerotiorum following outbreaks of lettuce drop. Phytopathology 83:509-513.

14. Boland, G. J. 1992. Hypovirulence and double-stranded RNA in Sclerotinia sclerotiorum. Can J. Plant Pathol. 14:10-17.

15. Boland, G. J. 1994. Index of plant hosts of Sclerotinia sclerotiorum. Can J. Plant Pathol. 16:93-108.

16. Burgess, D. R., and Hepworth, G. 1996. Examination of sclerotial germination in Sclerotinia minor with an in vitro model. Can. J. Bot. 74:450-455.

17. Cook, G. E., Steadman, J. R., and Boosalis, M. G. 1975. Survival of Whetzelinia sclerotiorum and initial infection of dry edible beans. Phytopathology 65:250-255

18. Coyne, D. P., Steadman, J. R., and Anderson, F. N. 1974. Effect of modified plant architecture of Great Northern dry bean varieties (Phaseolus vulgaris) on white mold severity, and components of yield. Plant Dis. Rep. 58:379-382.

19. Dillard, H. R., and Grogan, R. G. 1985. Influence of green manure crops and lettuce on sclerotial populations of Sclerotinia minor. Plant Dis. 69:579-582.

20. Dillard, H. R., Ludwig, J. W., and Hunter, J. E. 1995. Conditioning of sclerotia of Sclerotinia sclerotiorum for carpogenic germination. Plant Dis. 79:411-415.

21. Ferrar, P. H., and Walker, J. R. L. 1993. odiphenol oxidase inhibition - an additional role for oxalic acid in the phytopathogenic arsenal of Sclerotinia sclerotiorum and Sclerotium rolfsii. Physiol. Mol. Plant Pathol. 43:415-422.

22. Gerlagh, M., Kruse, M., van de Geijn, H. M., and Whipps, J. M. 1994. Growth and survival of the mycoparasite Coniothyrium minitans on lettuce leaves in contact with soil in the presence or absence of Sclerotinia sclerotiorum. Eur. J. Plant Pathol. 100:55-59.

23. Gilbert, R. G. 1991. Burning to reduce sclerotia of Sclerotinia sclerotiorum in alfalfa seed fields of southeastern Washington. Plant Dis. 75:141-142.

24. Godoy, G., Steadman, J. R., Dickman, M. B., and Dam, R. 1990. Use of mutants to demonstrate the role of oxalic acid in pathogenicity of Sclerotinia sclerotiorum on Phaseolus vulgaris. Physiol. Mol. Plant Pathol. 37:179-192.

25. GraciaGarza, J. A., Reeleder, R. D., and Paulitz, T. C. 1997. Degradation of sclerotia of Sclerotinia sclerotiorum by fungus gnats (Bradysia coprophila) and the biocontrol fungi Trichoderma spp. Soil Biol. Biochem.
29:123-129.

26. Grogan, R. G., Sall, M. A., and Punja, Z. K. 1980. Concepts for modeling root infection by soilborne fungi. Phytopathology 70:361363.

27. Hawthorne, B. T. 1975. Effect of mulching on the incidence of Sclerotinia minor on lettuce. N.Z. J. Exp. Agric. 3:273-274.

28. Hawthorne, B. T. 1976. Observations on the development of apothecia of Sclerotinia minor Jagg. in the field. N.Z. J. Agric. Res. 19:383-386

29. Hawthorne, B. T. 1979. Effectiveness of benomyl for control of Sclerotinia minor on lettuce. N.Z. J. Exp. Agric. 7:215-219.

30. Hubbard, J. C., Subbarao, K. V., and Koike, S. T. 1997. Development and significance of dicarboximide resistance in Sclerotinia minor isolates from commercial lettuce fields in California. Plant Dis. 81:148-153.

31. Imolehin, E. D., and Grogan, R. G. 1980 Effects of oxygen, carbon dioxide, and ethylene on growth, sclerotial production, germination, and infection by Sclerotinia minor. Phytopathology 70:1158-1161.

32. Imolehin, E. D., and Grogan, R. G. 1980 Factors affecting survival of sclerotia, and effects of inoculum density, relative position, and distance of sclerotia from the host on infection of lettuce by Sclerotinia minor. Phytopathology 70:1162-1167.

33. Imolehin, E. D., Grogan, R. G., and Duniway, J. M. 1980. Effect of temperature and moisture tension on growth, sclerotial production, germination, and infection by Sclerotinia minor. Phytopathology 70:1153-1157.

34. Jagger, I. C. 1920. Sclerotinia minor, n. sp.,

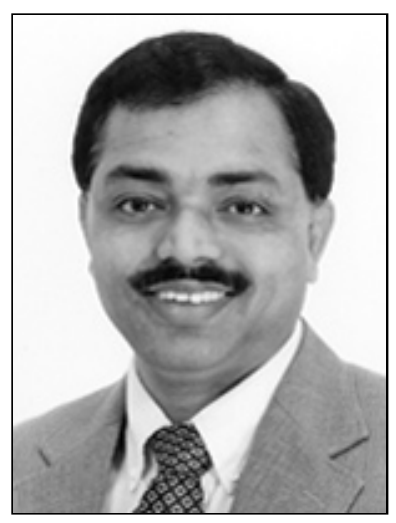

Krishna V. Subbarao

Dr. Subbarao is an associate plant pathologist/cooperative extension specialist with the Department of Plant Pathology, University of California, Davis, located at the U.S. Agricultural Research Station in Salinas. $\mathrm{He}$ received his B.S. in chemistry, botany, and zoology, and his M.S. in botany (plant pathology) from the University of Mysore, India, and his Ph.D. from Louisiana State University. He also had postdoctoral stints at Louisiana State University and the University of California, Berkeley, from 1989 to 1992. His current research focus is on etiology, epidemiology, and management of diseases of cool-season vegetable crops, with emphasis on inoculum dynamics of various soilborne pathogens influenced by cultivars, tillage practices, irrigation systems, and crop rotation. 
the cause of a decay of lettuce, celery, and other crops. J. Agric. Res. 20:331-333.

35. Kohn, L. 1979. Delimitation of the economically important plant pathogenic Sclerotinia species. Phytopathology 69:881-886.

36. Koike, S. T. 1994. Evaluation of biocontrol agents for control of lettuce drop, 1992. Biol. Cult. Tests 9:30.

37. Koike, S. T., Smith, R. F., Jackson, L. E., Wyland, L. J., Inman, J. I., and Chaney, W. E. 1996. Phacelia, Lana woollypod vetch, and Austrian winter pea: Three new cover crop hosts of Sclerotinia minor in California. Plant Dis. 80:1409-1412.

38. Kuo, S., Sainju, U. M., and Jellum, E. J. 1997. Winter cover crop effects on soil organic carbon and carbohydrate in soil. Soil Sci. Soc. Am. J. 61:145-152.

39. Lumsden, R. D. 1979. Histology and physiology of pathogenesis in plant diseases caused by Sclerotinia species. Phytopathology 69:890-896.

40. Marciano, P., Di Lenna, P., and Magro, P. 1983. Oxalic acid, cell wall degrading enzymes and $\mathrm{pH}$ in pathogenesis and their significance in the virulence of two Sclerotinia sclerotiorum isolates on sunflower. Physiol. Plant Pathol. 22:339-345.

41. Marcum, D. B., Grogan, R. G., and Greathead, A. S. 1977. Fungicide control of lettuce drop caused by Sclerotinia sclerotiorum 'minor'. Plant Dis. Rep. 61:555-559.

42. Martin, C., Davet, P., Vega, D., and Coste, C. 1991. Field effectiveness and biodegradation of cyclic imides in lettuce field soils. Pestic. Sci. 32:427-438.

43. McLaren, D. L., Huang, H. C., and Rimmer, S. R. 1996. Control of apothecial production of Sclerotinia sclerotiorum by Coniothyrium minitans and Talaromyces flavus. Plant Dis. 80:1373-1378.

44. Melzer, M. S., and Boland, G. J. 1996.
Transmissible hypovirulence in Sclerotinia minor. Can. J. Plant Pathol. 18:19-28.

45. Melzer, M. S., Smith, E. A., and Boland, G. J. 1997. Index of plant hosts of Sclerotinia minor. Can. J. Plant Pathol. 19:272-280.

46. Michelmore, R. W. 1997. Application of biotechnology to disease resistance in lettuce. Pages 11-13 in: Compendium of Lettuce Diseases. R. M. Davis, K. V. Subbarao, R. N. Raid, and E. A. Kurtz, eds. American Phytopathological Society, St. Paul, MN.

47. Mitchell, S. J and Wheeler, B. E. J. 1990. Factors affecting the production of apothecia and longevity of sclerotia of Sclerotinia sclerotiorum. Plant Pathol. 39:70-76.

48. Newton, H. C., and Sequeira, L. 1972. Possible sources of resistance in lettuce to Sclerotinia sclerotiorum. Plant Dis. Rep. 56:875-878.

49. Noyes, R. D., and Hancock, J. G. 1981. Role of oxalic acid in sclerotinia wilt of sunflower. Physiol. Plant Pathol. 18:123-132.

50. Patterson, C. L., and Grogan, R. G. 1985. Differences in epidemiology and control of lettuce drop caused by Sclerotinia minor and S. sclerotiorum. Plant Dis. 69:766-770.

51. Patterson, C. L., and Grogan, R. G. 1988. Relationship of growth media and drying and of age of sclerotia to eruptive germination and infection by Sclerotinia minor. Plant Dis. 72:1046-1048

52. Phillips, A. J. L. 1990. The effects of soil solarization on sclerotial populations of Sclerotinia sclerotiorum. Plant Pathol. 39:38-43.

53. Purdy, L. H. 1979. Sclerotinia sclerotiorum: History, diseases and symptomatology, host range, geographic distribution, and impact. Phytopathology 69:875-880.

54. Ryder, E. J. 1997. Origin and history of lettuce, types of lettuce, and production. Pages 1-8 in: Compendium of Lettuce Diseases. R. M. Davis, K. V. Subbarao, R. N. Raid, and E. A. Kurtz, eds. American Phytopathological
Society, St. Paul, MN

55. Ryder, E. J. 1998. Lettuce, Endive, and Chicory. CAB International, Cambridge.

56. Smith, R. E. 1900. Botrytis and Sclerotinia, their relationship to certain plant diseases and to each other. Bot. Gaz. 29:407-423.

57. Stevens, F. L., and Hall, J. G. 1911. A serious lettuce disease (sclerotiniose) and a method of control. N.C. Agric. Exp. Stn. Tech. Bull. 8:85-145.

58. Subbarao, K. V. 1996. Epidemiology and control of lettuce drop caused by Sclerotinia minor. Annu. Lettuce Res. Rep. Crop Year 1995. Calif. Iceberg Lettuce Advisory Board, Salinas.

59. Subbarao, K. V. 1997. Lettuce Drop. Pages 19-21 in: Compendium of Lettuce Diseases. R M. Davis, K. V. Subbarao, R. N. Raid, and E. A Kurtz, eds. American Phytopathological Society, St. Paul, MN

60. Subbarao, K. V., and Hubbard, J. C. 1996. Interactive effects of broccoli residue and temperature on Verticillium dahliae microsclerotia in soil and on wilt in cauliflower. Phytopathology 86:1303-1310.

61. Subbarao, K. V., Hubbard, J. C., and Schulbach, K. F. 1997. Comparison of lettuce diseases and yield under subsurface drip and furrow irrigation. Phytopathology 87:877-883.

62. Subbarao, K. V., Koike, S. T., and Hubbard, J. C. 1996. Effects of deep plowing on the distribution and density of Sclerotinia minor sclerotia and lettuce drop incidence. Plant Dis. 80:28-33.

63. Teo, B. K., Verma, P. R., and Morrall, R. A. A. 1992. The effects of herbicides and mycoparasites at different moisture levels on carpogenic germination in Sclerotinia sclerotiorum. Plant Soil 139:99-107.

64. Walker, A. 1987. Further observations on the enhanced degradation of iprodione and vinclozolin in soil. Pestic. Sci. 21:219-231. 